\title{
Segmentasi Citra Janin pada Citra Ultrasonografi (USG) Janin Menggunakan Metode Prewitt dan Canny
}

\author{
${ }^{1}$ Selviana, ${ }^{2}$ Tri Deviasari Wulan \\ ${ }^{1,2}$ Program Studi S1 Sistem Informasi, Universitas Nahdlatul Ulama Surabaya \\ ${ }^{1}$ anaselvi6999@gmail.com ${ }^{2}$ tridevi@unusa.ac.id
}

\begin{abstract}
Abstrak-Ultrasonografi (USG) merupakan alat yang digunakan untuk mendeteksi kondisi kesehatan janin pada ibu hamil. Penggunaan USG yang dilakukan untuk mengetahui anatomi (perkembangan) janin maka perlu dilakukan USG janin. Tipe USG 2D banyak dipilih oleh ibu hamil karena harganya murah dan mudah didapatkan di Rumah Sakit dan Puskesmas. USG janin dua dimensi sendiri memiliki kekurangan seperti banyaknya derau yang terdapat pada citra dan bentuk dari antomi janin yang tidak terlalu terlihat. Penelitian ini bertujuan untuk mendapatkan hasil segmentasi dari citra USG 2D. Tahapan penelitian memiliki tiga langkah yaitu pra-pemrosesan, deteksi tepi dan penilaian akurasi. Preprosessing Citra USG 2D bertujuan untuk mengubah citra asli menjadi citra biner dan filtering citra. Tahapan kedua, segmentasi citra menggunakan deteksi tepi memiliki tujuan untuk mendapatkan garis tepi yang terdapat pada citra. Proses segmentasi menggunakan metode deteksi tepi Prewitt dan Canny. Tahapan terakhir penilaian akurasi dengan membandingkan hasil sistem dan expert judgement. Hasil penelitian menunjukkan hasil akurasi segmentasi citra USG 2D menggunakan metode canny sebesar $65 \%$ lebih akurat dibandingkan dengan menggunakan metode Prewitt yang sebesar $62 \%$.
\end{abstract}

Kata Kunci- Segmentasi Citra, Deteksi Tepi, Prewitt, Canny, USG Janin,

\section{PENDAhUluan}

Citra merupakan salah satu bentuk dari komponen informasi yang dibutuhkan oleh manusia selain dari teks, video, dan suara. Namun dalam proses pengambilan citra terkadang terdapat mengalami penurunan mutu (kualitas) seperti mengandung derau (noise), kurang fokus (blur) sebuah citra atau gambar terlihat agak gelap dan sebagainya. Citra yang mengalami penurunan mutu tersebut perlu melakukan pengolahan citra untuk meningkatkan kualitas dari citra. Proses pengolahan dalam citra bertujuan untuk membantu manusia dalam menginterpretasikan objek yang tertangkap kamera dengan menggunakan teknik peningkatan kualitas citra. Selain itu, pengolahan citra digital juga digunakan sebagai pengindra mesin otomatis [6].

Di Indonesia, pemeriksaan Ultrasonografi (USG) janin pada umumnya menggunakan citra USG berdimensi dua (2D) seperti puskesmas atau rumah sakit di kota kecil. Sedangkan di beberapa rumah sakit atau klinik bersalin di kota besar telah menggunakan citra USG janin yang berdimensi tiga ataupun empat. Namun, USG 2D masih banyak dipilih oleh ibu hamil karena harganya yang lebih terjangkau dan mudah ditemukan. Hasil USG janin 2D memiliki beberapa kelemahan yaitu terkadang memiliki penurunan kualitas, yang dapat berupa rentang kontras, distorsi geometrik, kekaburan dan noise. Karena penurunan kualitas citra USG 2D, ibu hamil tidak dapat memperoleh informasi dengan jelas terkait kondisi janin. Informasi yang hilang sendiri yaitu bentuk janin yang tidak jelas karena tertutup derau dan hanya menghasilkan gambaran datar berdimensi dua hitam putih dari janin.

Deteksi tepi merupakan salah satu metode yang digunakan untuk segmentasi pada pengolahan citra digital. Tujuan dari metode ini untuk memperoleh tepi yaitu garis yang memisahkan antara objek dan latar belakang (Susanto, 2012). Citra USG 2D perlu dilakukan segmentasi menggunakan deteksi tepi untuk memperjelas atau mempertebal tepian janin. Metode deteksi tepi yang banyak digunakan yaitu prewitt dan canny. Metode canny banyak digunakan dalam penelitian karena dikenal sebagai algoritma deteksi tepi paling optimal. Sedangkan metode prewitt banyak digunakan dalam berbagai penelitian karena algoritma prewitt lebih peka terhadap garis horizontal dan vertical [3].

Beberapa penelitian tentang peningkatan kualitas citra yaitu, penelitian telah dilakukan oleh Nurul Baety Tsani pada tahun 2019 menggunakan citra kanker serviks menggunakan metode kolposkopi kolposkopi adalah pemeriksaan dini untuk melihat permukaan serviks dengan memasukkan alat bernama kolposkop kedalam liang vagina. Gambar permukaan serviks bisa didokumentasikan dengan menggunakan kamera kecil yang terdapat pada kolposkop. Petugas medis hanya mengandalkan visual (mata) untuk menganalisis citra ini. Dengan kata lain, keakuratan dan ketepatan analisis objek sangat tergantung pada kondisi dan keadaan petugas medis tersebut sehingga dinilai kurang efisien. Penelitian ini akan membahas tentang pengolahan citra yang dilakukan untuk mendeteksi kanker serviks dengan teknik segmentasi berbasis deteksi tepi terhadap citra serviks menggunakan kombinasi algoritma canny dengan transformasi powerlaw. Pengambilan informasi dari sebuah citra harus dilakukan melalui pemrosesan citra. Deteksi tepi merupakan langkah penting dalam proses pengolahan citra digital dan termasuk sebagai langkah awal dalam untuk pengenalan pola.

Penelitian lain dilakukan oleh Rizki Nanda dkk pada tahun 2019 Segmentasi Citra Medis untuk Deteksi Objek FAM pada Payudara. Metode yang digunakan yaitu dengan melakukan proses segmentasi citra asli dengan mendeteksi garis tepi pada gambar kemudian hasil segmentasi dikonversi ke dalam citra biner agar sistem dapat menentukan area FAM. Segmentasi citra medis menggunakan metode Sobel dilakukan untuk menentukan tepi pada objek FAM karena batas tepi dapat terlihat dengan jelas. Namun untuk sebagian citra dengan resolusi yang kurang seperti yang telah dilakukan pada uji coba sebelumnya, deteksi tepi ini akan sulit dalam 
menentukan tepi pada objek yang halus dan hanya membentuk garis tepi yang kasar.

Pada penelitian ini akan dilakukan perbaikan kualitas citra USG janin berdimensi dua dengan menggunakan metode prewitt dan canny. Hal ini bertujuan agar bentuk anatomi janin pada citra USG janin berdimensi dua dapat teridentifikasi dengan jelas, seperti bentuk anatomi janin yang akan terdeteksi dengan menggunakan deteksi tepi dan kelainan pada janin yang terdapat pada citra USG janin. Sehingga dari hasil segmentasi citra USG berdimensi dua ini akan memberikan informasi lebih kepada dokter dan ibu hamil terkait anatomi janin yang dimiliki.

\section{Metodologi Penelitian}

Metodologi penelitian ini berisi langkah-langkah dan penjelasan yang dilakukan pada penelitian Segmentasi citra janin pada citra USG janin dua dimensi menggunakan metode Prewitt dan canny langkah-langkah tersebut digambarkan pada gambar 1.

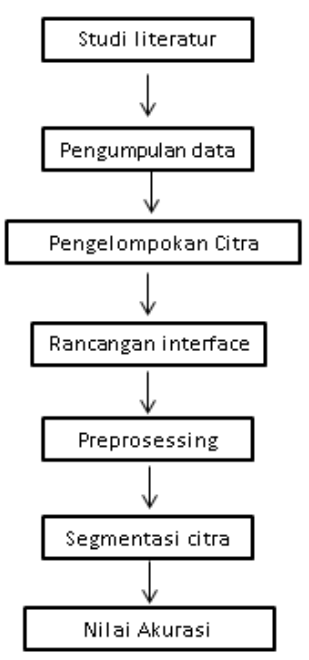

Gbr 1. Diagram Alur Metode Penelitian

\section{A. Studi Literatur}

Pada tahap ini dilakukan pegumpulan data pustaka, dengan membaca dan mencatat bahan-bahan studi literarur yang peneliti dapatkan dari jurnal, artikel dan e-book dari internet yang berhubungan dengan segmentasi citra menggunakan metode prewritt dan canny.

\section{B. Pengumpulan Data}

Data yang digunakan pada penelitian ini adalah citra USG 2D yang didapatkan dari Wikimedia commons database. Contoh data citra USG 2D yang digunakan dalam penelitian ini ditunjukkan pada gambar 2 .

Citra yang digunakan dalam penelitian ini berjumlah 35 citra USG 2D yang terdiri dari dari 3 kategori yaitu citra USG 2D Trimester 1, USG 2D Trimester 2, dan USG 2D Trimester 3 .

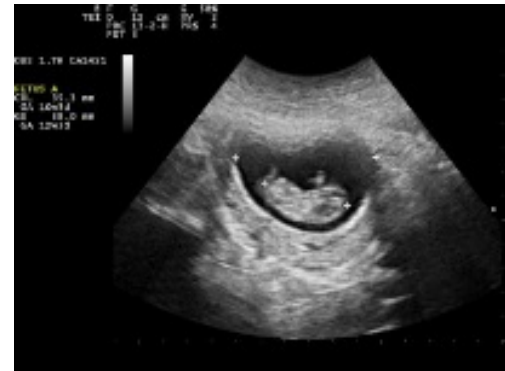

Gbr 2. Contoh data Citra USG 2D

\section{Pengelompokkan Data}

Pengelompokan data dibagi menjadi 3 kategori trimester yaitu Trimester 1, 2 dan 3. Pengelompokan USG 2D ini bertujuan untuk mempermudah proses segmentasi citra dan proses perhitungan akurasi yang dilakukan berdasarkan trimester janin.

\section{Perancangan interface}

Pada tahap ini akan menjelaskan rancangan antar muka (interface) yang bertujuan untuk mempermudah dalam menjalankan program yang dijalankan menggunakan sortware matlab. Desain interface dibuat menggunakan Graphical User Interface (GUI) yang ditampilkan pada Gambar 3. Desain GUI dan pembuatan sistem menggunakan tools Matlab.

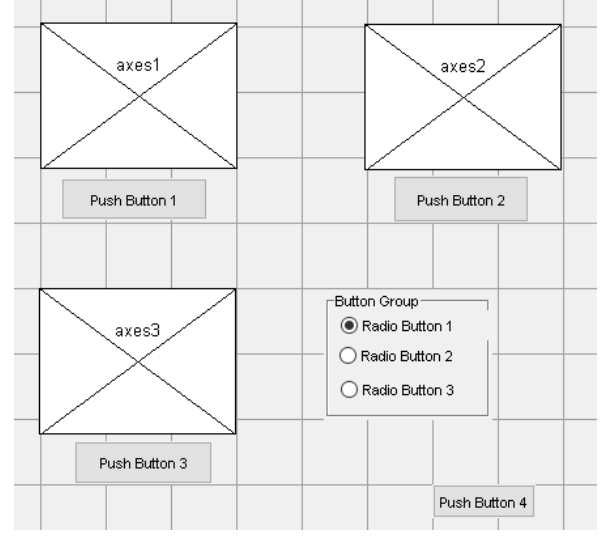

Gbr 3. Rancangan Interface

\section{E. Pre-Prossesing}

Prepossessing merupakan tahap pengolahan citra memiliki tiga tahap yaitu image cropping, binary citra, dan filtering image. Image cropping yaitu menghilangkan bagian dari citra yang tidak diperlukan untuk mendapatkan area anatomi janin. Proses cropping dilakukan secara manual. Setelah citra hasil cropping, tahap selanjutnya yaitu filtering dengan menggunakan software matlab. Proses binary citra. proses ini bertujuan untuk mengubah citra asli menjadi cira biner. Proses terakhir yaitu Proses filtering yang digunakan yaitu filter median yang berfungsi untuk menghilangkan noise dan memperhalus citra USG janin penggunaan median filtering bertujuan untuk menghilangkan noise yang terdapat pada citra biner . 


\section{F. Segmentasi}

Segmentasi citra merupakan proses yang ditujukan untuk mendapatkan objek-objek yang terkandung di dalam citra atau membagi citra ke dalam beberapa daerah dengan setiap objek atau daerah memiliki kemiripan atribut. Deteksi tepi merupakan salah satu metode yang digunakan untuk melakukan segmentasi citra. Penelitian ini menggunakan deteksi tepi sebagai proses segmentasi citra USG 2D. Hal ini bertujuan untuk memperbaiki kualitas citra yang kabur karena efek dari akuisisi dari sistem. Terdapat 2 metode deteksi tepi yang digunakan dalam penelitian ini yaitu metode prewiit dan canny.

\section{Metode Prewitt}

Metode prewitt menggunakan persamaan yang sama dengan operator sobel, hanya saja konstanta $\mathrm{C}$ yang digunakan bernilai 1. Operator prewitt tidak menekankan pembobotan pada piksel - piksel yang lebih dekat dengan titik pusat kernel. Metode ini mengambil prinsip dari fungsi laplacian yang dikenal sebagai fungsi untuk membangkitkan High Pass Filter. Metode prewitt banyak digunakan dalam berbagai penelitian karena algoritma prewitt lebih peka terhadap garis horizontal dan vertikal.

$$
\mathrm{Sx}=\left(\begin{array}{cc}
1 & 0-1 \\
1 & 0-1 \\
1 & 0-1
\end{array}\right) \text { dan } \operatorname{ly}\left(\begin{array}{ccc}
-1 & -1 & -1 \\
0 & 0 & 0 \\
1 & 1 & -1
\end{array}\right)
$$

\section{Metode Canny}

Metode canny yang dikemukakan oleh John Canny pada tahun 1986, terkenal sebagai operator deteksi tepi yang optimal. Algoritma ini memberikan tingkat kesalahan rendah, melokalisasi titik-titik tepi (jarak piksel-piksel yang ditemukan deteksi dan tepi yang sesungguhnya sangat pendek) dan hanya memberikan satu tanggapan untuk satu tepi. Metode canny sendiri banyak digunakan dalam penelitian karena dikenal sebagai algoritma deteksi tepi paling optimal

\section{G. Perhitungan akurasi}

Perhitungan akurasi bertujuan untuk mendapatkan tingkat keberhasilan dari system yang dibuat oleh peneliti. Perhitungan akurasi ini menggunakan data uji USG 2D sejumlah 35 USG 2D dari masing-masing trimester. Dari hasil pengujian citra yang telah dilakukan maka perhitungan akurasi dapat diperoleh melalui rumus persentase :

$$
\text { presentasi akurasi }=\frac{\text { jumlah citra yang sesuai }}{\text { jumlah keseluruhan citra uji }} x 100 \%
$$

Jumlah citra yang sesuai adalah data yang diambil dari kolom kesimpulan, jumlah keseluruhan citra uji diambil dari jumlah citra usg janin dua dimensi yang digunakan.

\section{HASIL DAN PEMBAHASAN}

\section{A. Pengumpulan Data}

Data yang dikumpulkan pada penelitian ini adalah citra usg janin berdimensi dua berjumlah 35 citra USG 2D . Data tersebut terdiri dari dari 3 kategori yaitu citra USG 2D Trimester 1, citra USG 2D Trimester 2, dan citra USG 2D Trimester 3. Jumlah data pada tiap trimester ditunjukkan pada tabel 1 dan Pengelompokan Citra USG 2D berdasarkan trimester ditunjukkan pada tabel I.

TABEL I.

PENGELOMPOKAN CITRA USG 2D

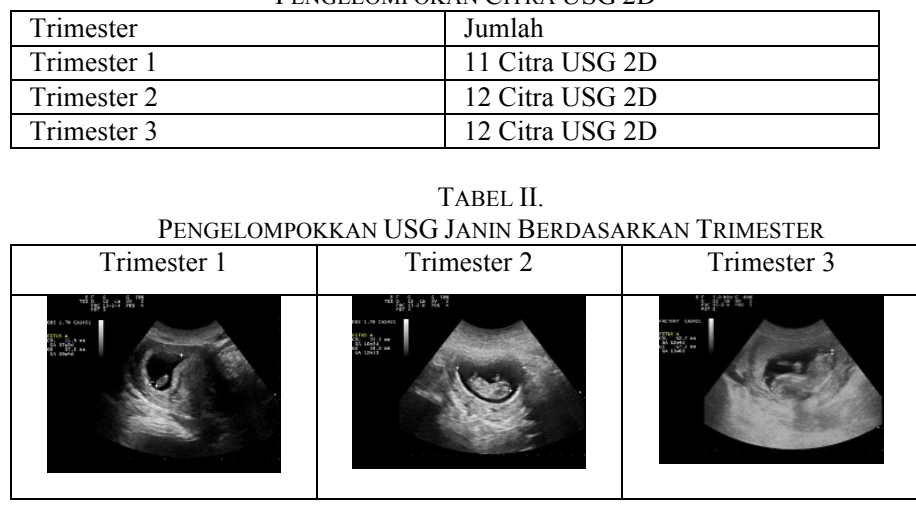

\section{B. Tampilan Aplikasi}

Desain Interface aplikasi dibuat untuk mempermudah dalam menjalankan program program yang dijalankan menggunakan sortware matlab. Pada gambar 3 menunjukkan tampilan utama desain interface aplikasi sebelum data citra di proses. Dan pada gambar 4 adalah tampilan sesudah data citra dimasukkan.

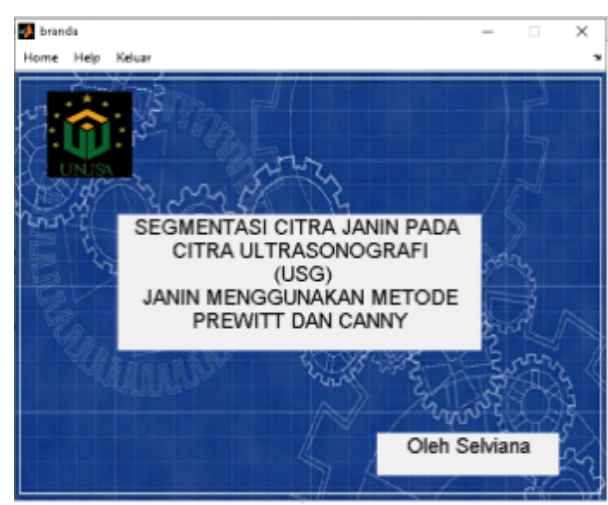

Gbr 4. Tampilan Awal Aplikasi 


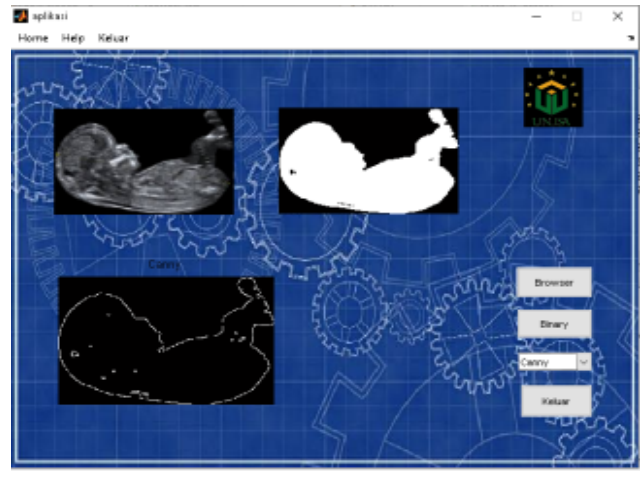

Gbr 5. Tampilan Aplikasi Setelah di Proses

\section{Pre-Posessing Citra}

Pada tahap ini dilakukan 3 tahap, yang pertama yaitu tahap image cropping, binary citra dan image filtering.

1) Cropping

Tahap cropping dilakukang dengan menggunakan software picsart untuk memudahkan proses cropping. Proses cropping bertujuan untuk mendapatkan objek janin dan menhilangkan area kandungan yang tidak diperlukan. Hasil Cropping Citra USG 2D ditunjukkan pada Gambar 5.

\begin{tabular}{|l|c|c|}
\hline Trimester 1 & Trimester 2 & Trimester 3 \\
\hline & & \\
\hline
\end{tabular}

Gbr 6. Hasil Cropping Citra USG 2D

\section{2) Tahap Binary}

Tahap binary bertujuan mengubah citra asli menjadi citra biner dengan mengganti semua piksel dengan nilai 1(putih) dan nilai 0 (hitam). Hasil tahapan binary citra ditunjukkan pada Gambar 6.

\begin{tabular}{|l|c|c|}
\hline Trimester 1 & Trimester 2 & Trimester 3 \\
\hline Tahap Binary & & \\
\hline
\end{tabular}

Gbr 7. Hasil Tahap Binary

\section{3) Image filtering}

Image filtering bertujuan untuk menghilangkan noise yang terdapat pada citra biner. Image filtering yang digunakan yaitu filter median yang berfungsi untuk menghilangkan noise dan memperhalus citra USG janin.. Pada proses ini citra usg janin akan di proses dengan menggunakan filter median untuk menghilangkan derau dan mempertajam citra dan peningkatan tepi. Proses ini bertujuan untuk mengubah citra hasil biner kedalam citra hasil filtering median

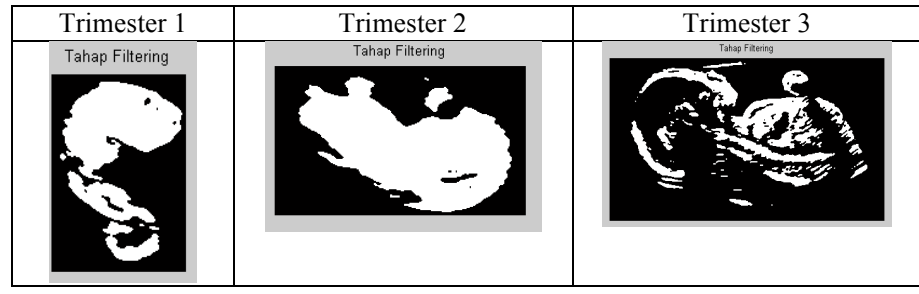

Gbr 8. Hasil Median Filtering

\section{Segmentasi Citra}

penggunaan Segmentasi citra pada penelitian ini yaitu deteksi tepi. Deteksi tepi bertujuan untuk mendapatkan tepi objek yang terdapat pada citra usg janin berdimensi dua. deteksi tepi yang digunakan dalam penelitian ini ada dua yaitu Prewritt dan Canny. Penelitian ini dilakukan dengan menggunakan software matlab 2013.

1) Deteksi Tepi Canny

Deteksi tepi canny dikenal sebagai algoritma deteksi tepi paling optimal penggunaan deteksi tepi ini bertujuan untuk mendapatkan hasil optimal.

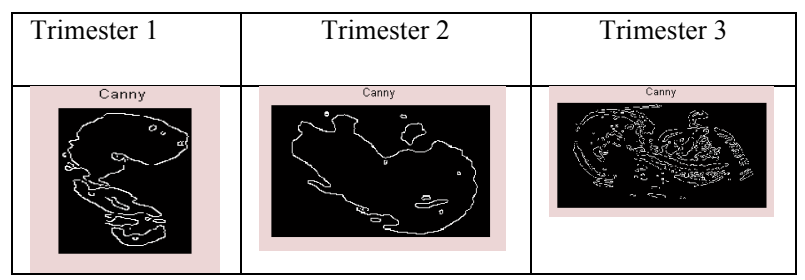

Gbr 9. Hasil deteksi Tepi Canny

Hasil analisa yang dilakukan menggunakan metode pengolahan deteksi tepi canny menunjukkan hasil yang optimal seperti yang ditunjukkan pada citra trimester kedua yang mana menunjukkan garis tepi yang tebal dan tidak terputus-putus.

2) Deteksi Tepi Prewitt

Deteksi tepi prewitt dikenal dengan algoritma yang lebih peka terhadap garis horizontal dan vertikal

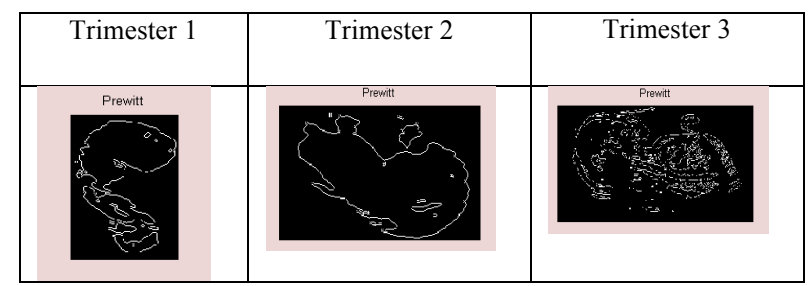

Gbr 10. Hasil deteksi Tepi Prewitt

Hasil analisa yang dilakukan menggunakan metode pengolahan deteksi tepi prewitt menunjukkan hasil yang kurang optimal seperti yang ditunjukkan pada citra trimester ketiga yang mana menunjukkan garis tepi yang kurang tebal dan terputus-putus. 
3). Perbandingan Hasil Deteksi Tepi Canny dan Prewitt

\begin{tabular}{|l|l|}
\hline Deteksi tepi canny & Deteksi tepi prewitt \\
\hline
\end{tabular}

Gambar 11. Perbandingan Hasil Deteksi Tepi Canny dan Prewitt

Berdasarkan dari deteksi tepi canny dan prewitt yang dilakukan peneliti menemukan perbedaan antara hasil dari canny dan prewitt, seperti ditunjukkan pada gambar 9. Hasil dari deteksi tepi canny menghasilkan deteksi tepi paling baik yang mana menunjukkan garis tepi yang tebal dan tidak terputus-putus. Sedangkan deteksi tepi prewitt menunjukkan hasil kurang optimal yang mana menunjukkan garis tepi yang kurang tebal dan terputus-putus.

\section{E. Perhitungan Akurasi}

Perhitungan akurasi ini untuk mendapatkan tingkat keberhasilan dari sistem (yang dibuat oleh peneliti). Perhitungan akurasi ini menggunakan data uji usg dua dimensi dengan jumlah 35 USG 2D dari masing-masing trimester. Perhitungan akurasi ini didapatkan dari perbandingan dari aplikasi yang telah dibuat dengan hasil expert judgement. Kesimpulan didapatkan berdasarkan hasil dari kesesuaian gambar pengujian yang ditampilkan oleh sistem dengan Data masukan USG janin yang digunakan. Dari hasil pengujian akan didapatkan keterangan seperti yang ada pada tabel 3 dan 4.

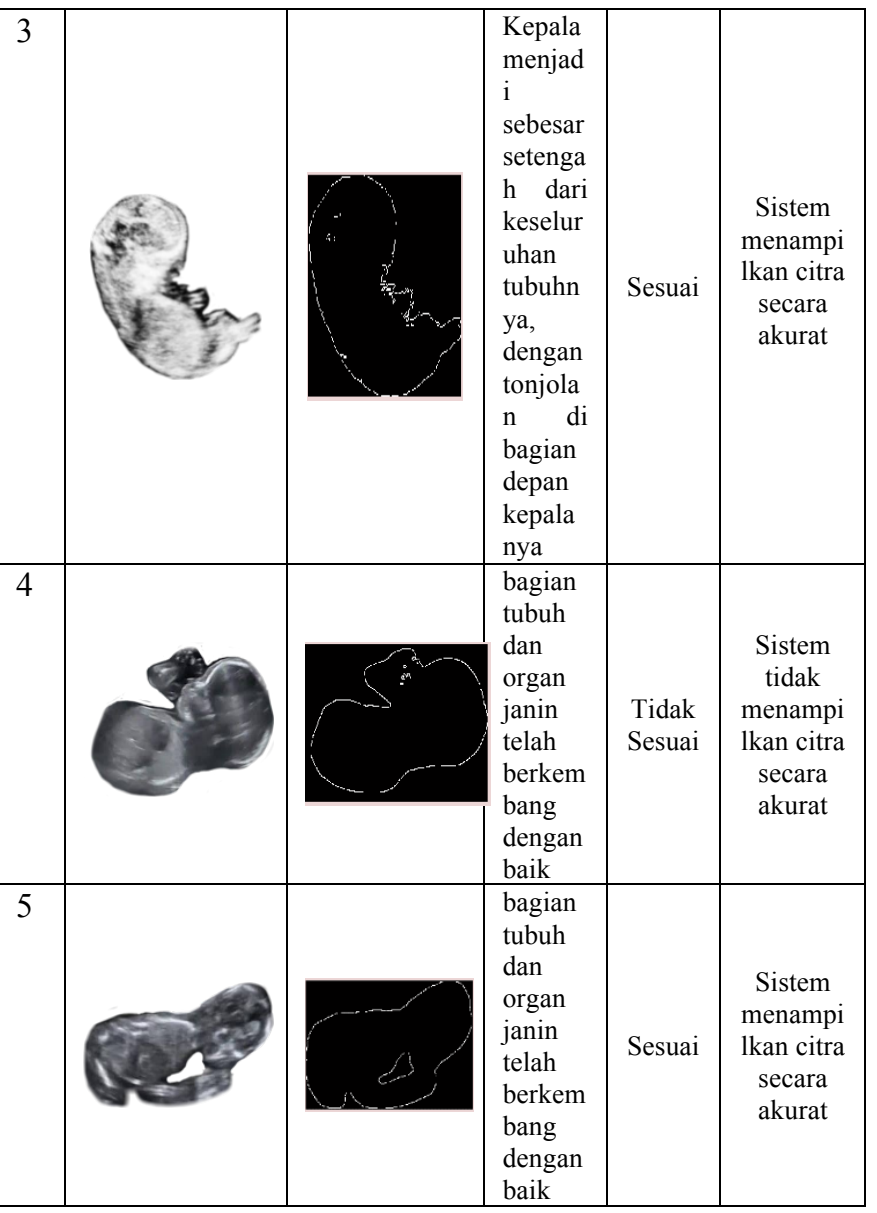

TABEL III.

PERHITUNGAN AKURASI CANNY

\begin{tabular}{|c|c|c|c|c|c|}
\hline \multirow[t]{2}{*}{$\begin{array}{l}\mathrm{N} \\
\mathrm{o} .\end{array}$} & \multirow[t]{2}{*}{ Data Masukan } & \multirow{2}{*}{$\begin{array}{l}\text { Hasil } \\
\text { pengujian } \\
\text { sistem deteksi } \\
\text { tepi Canny }\end{array}$} & \multicolumn{2}{|c|}{$\begin{array}{l}\text { Hasil expert } \\
\text { judgeme } \\
\text { nt }\end{array}$} & \multirow[t]{2}{*}{$\begin{array}{l}\text { Kesimpu } \\
\text { lan }\end{array}$} \\
\hline & & & Bentuk & $\begin{array}{l}\text { Keses } \\
\text { uaian }\end{array}$ & \\
\hline 1 & & & $\begin{array}{l}\text { Embrio } \\
\text { mulai } \\
\text { berbent } \\
\text { uk }\end{array}$ & Sesuai & $\begin{array}{c}\text { Sistem } \\
\text { menampi } \\
\text { lkan citra } \\
\text { secara } \\
\text { akurat }\end{array}$ \\
\hline 2 & & & $\begin{array}{l}\text { Tampil } \\
\text { an } \\
\text { pada } \\
\text { wajah } \\
\text { mulai } \\
\text { berbent } \\
\text { uk,den } \\
\text { gan } \\
\text { hidung } \\
\text { dan } \\
\text { kelopa } \\
\text { k mata } \\
\text { yang } \\
\text { mulai } \\
\text { tampak }\end{array}$ & Sesuai & $\begin{array}{c}\text { Sistem } \\
\text { menampi } \\
\text { lkan citra } \\
\text { secara } \\
\text { akurat }\end{array}$ \\
\hline
\end{tabular}

TABEL IV.

PERHITUNGAN AKURASI PREWITT

\begin{tabular}{|c|c|c|c|c|c|}
\hline \multirow[t]{2}{*}{$\begin{array}{l}\mathrm{N} \\
\mathrm{o}\end{array}$} & \multirow[t]{2}{*}{ Data Masukan } & \multirow{2}{*}{$\begin{array}{l}\text { Hasil pengujian } \\
\text { sistem deteksi tepi } \\
\text { Canny }\end{array}$} & \multicolumn{2}{|c|}{$\begin{array}{l}\text { Hasil expert } \\
\text { judgement }\end{array}$} & \multirow[t]{2}{*}{$\begin{array}{l}\text { Kesim } \\
\text { pulan }\end{array}$} \\
\hline & & & Bentuk & $\begin{array}{l}\text { Keses } \\
\text { uaian }\end{array}$ & \\
\hline 1 & & & $\begin{array}{l}\text { Embri } \\
\text { o } \\
\text { mulai } \\
\text { berben } \\
\text { tuk }\end{array}$ & Sesuai & $\begin{array}{c}\text { Siste } \\
\text { m } \\
\text { mena } \\
\text { mpilk } \\
\text { an } \\
\text { citra } \\
\text { secara } \\
\text { akurat }\end{array}$ \\
\hline 2 & & & $\begin{array}{l}\text { Kepala } \\
\text { menjad } \\
\mathrm{i} \\
\text { sebesar } \\
\text { seteng } \\
\text { ah dari } \\
\text { keselur } \\
\text { uhan } \\
\text { tubuhn } \\
\text { ya, } \\
\text { dengan } \\
\text { tonjola } \\
\text { n di } \\
\text { bagian } \\
\text { depan } \\
\text { kepala } \\
\text { nya }\end{array}$ & Sesuai & $\begin{array}{c}\text { Siste } \\
\text { m } \\
\text { mena } \\
\text { mpilk } \\
\text { an } \\
\text { citra } \\
\text { secara } \\
\text { akurat }\end{array}$ \\
\hline
\end{tabular}




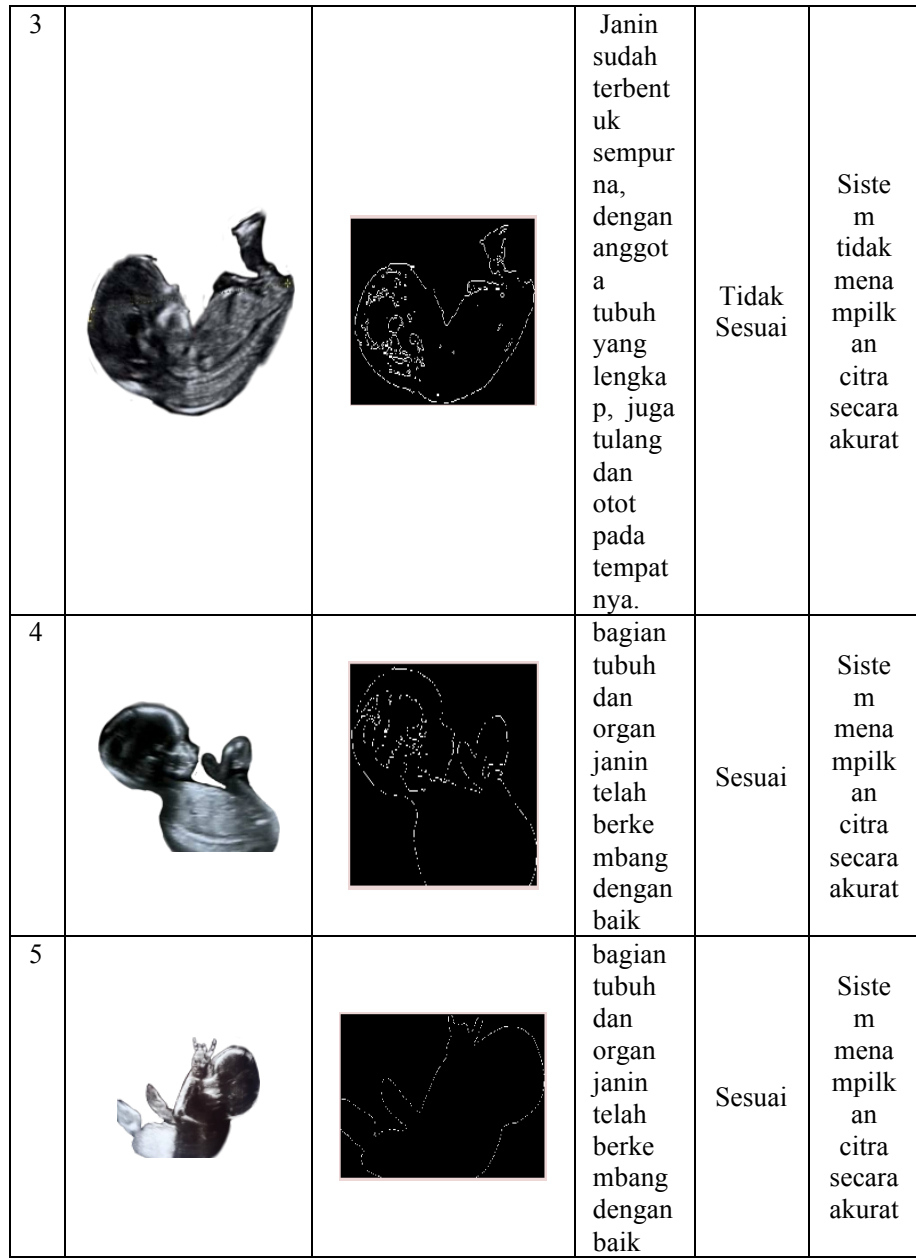

Berdasarkan hasil deteksi menggunakan metode canny yang ditunjukkan pada tabel 3 , dari 35 citra usg janin terdapat 23 citra yang sesuai kriteria dan 12 citra usg janin tidak sesuai kriteria dan mendapatkan hasil keakuratan sebesar $65 \%$.

$$
\begin{gathered}
\text { persentase akurasi }=\frac{\text { jumlah citra yang sesuai }}{\text { jumlah keseluruhan citra uji }} \times 100 \% \\
\text { persentase akurasi }=\frac{23}{35} \times 100 \%=65 \%
\end{gathered}
$$

Sedangkan pada hasil deteksi menggunakan metode prewitt (tabel 4) menunjukkan keakuratan sebesar $62 \%$.

$$
\begin{gathered}
\text { persentase akurasi }=\frac{\text { jumlah citra yang sesuai }}{\text { jumlah keseluruhan citra uji }} \times 100 \% \\
\text { persentase akurasi }=\frac{22}{35} \times 100 \%=62 \%
\end{gathered}
$$

Hasil akurasi menunjukkan sebagian besar citra USG 2D pada trimester 3 yang mendapatkan hasil tidak sesuai, baik menggunakan metode canny maupun sobel. Pada trimester 3 organ tubuh sudah mulai lengkap dan deteksi tepi canny hanya mendeteksi bagian luarnya saja, sedangkan yang bagian tapian dalam tidak terdeteksi. Hal ini disebabkan oleh kontras pada citra USG 2D rendah, sehingga deteksi tepi canny tidak dapat mendeteksi mendeteksi tepi bagian tengah citra dan hanya mendeteksi tepi bagian luar citra usg janin

\section{KeSIMPULAN}

Kesimpulan yang didaptak dari penelitian ini antara lain :

a. Hasil percobaan dari proses segmentasi citra USG janin berdimensi dua menggunakan metode prewitt dan canny penelitian, berdasarkan penelitian pada 35 citra masukan usg janin didapatkan hasil kesesuaian citra yang terdeteksi dengan menggunakan metode canny mendapatkan hasil keakuratan sekitar 65\%. Sedangkan metode prewitt mendapatkan hasil keakuratan sekitar $62 \%$.

b. Berdasarkan hasil perbandingan dari metode canny dan prewitt didapatkan perbedaan yang cukup kontras dimana hasil deteksi tepi canny menghasilkan deteksi tepi paling baik yang mana menunjukkan garis tepi yang tebal dan tidak terputus-putus. Sedangkan deteksi tepi prewitt menunjukkan hasil kurang optimal yang mana menunjukkan garis tepi yang kurang tebal dan terputusputus.

\section{UCAPAN TERIMAKASIH}

Pada kesempatan ini penulis menyampaikan ucapan terima kasih yang tiada terhingga kepada beberapa pihak diantaranya sebagai berikut:

1. Universitas Nahdlatul Ulama Surabaya

2. Dosen $\mathrm{S} 1$ Sistem Informasi

\section{REFERENSI}

[1] Abdul, R. D. T. D. H. D., Implementasi Deteksi Tepi Canny Dengan Transformasi Powerlaw Dalam Mendeteksi Stadium Kanker Serviks. Jurnal Ilmiah Intech (Information Technology Journal) Of Umus, Pp. 2233.2019 .

[2] Ela, E. D. K. D. S. D., Penerapan Metode Canny Dalam Koreksi Lembar Jawaban Komputer Untuk Try Out. Prosiding Sentia - Politeknik Negeri Malang, P. Vol 9.2017.

[3] Eosina, F. D. L. D., Analisis Perbandingan Metode Prewitt Dan Canny Untuk. Prosiding Sintak 2017.

[4] Evrita, L. D. U. D., Analisa Deteksi Tepi Janin Dengan Menggunakan Metode Prewitt Dan Canny. Simposinium Nasional Rapi Xiv.2015.

[5] Komarudin, S. D. S. D. M.,Pengolahan Citra Dasar Dan Contoh Penerapannya. Yogyakarta: Teknosain.2016.

[6] Lyanda, A. D. E. D. S. D., J Respir Indo. Ultrasonografi Toraks, Pp. Vol. 31, No. 1.2011

[7] Polinus, Media Informatika Budidarma. Penerapan Metode Prewitt, Canny Dan Sobel Pada Proses Deteksi Tepi Citra, Pp. 45-50.2018. 
[8] Romodhon, A. D., Journal Of Research In Computer Scien And Aplication. Ekstraksi Bentuk Janin Pada Citra Hasil Usg 3 Dimensi Menggunakan Deteksi Tepi. 2012.

[9] Sukatmi, Perbandingan Deteksi Tepi Citra Digital Dengan Dengan Metode Prewitt Dan Canny. Kopertip: Jurnal Ilmiah Manajemen Informatika Dan Komputer, Pp. Vol 01,2017.

[10] Supriyanti, Teknologi Informasi (Tik) Untuk Ketahanan Nasional. Perhitungan Panjang Janin Pada Citra Ultrasonografi Untuk Memprediksi Usia Kehamilan2012..

[11] Susanto, K. D. Pengolahan Citra : Teori Dan Aplikasi. Yogyakarta: S.N.2012.

[12] Wulan, I. D. N. D., Segmentasi Citra Medis Untuk Deteksi Objek Fam Pada Payudara Menggunakan Metode Sobel. Jurnal Media Informatika Budidarma,, Pp. Vol 3, No 4.2019.

[13] Zalukhu, A. D., Implementasi Metode Canny Dan Sobel Untuk Mendeteksi Tepi Citra. Jurnal Riset Komputer (Jurikom), Pp. Vol. 3 No. 6,. 2016. 